\title{
Seed and seedling quality of three chilis (Capsicum annuum L.) native to Oaxaca, Mexico
}

\author{
Jair Sanjuan-Martínez ${ }^{1}$ (i) Yolanda Donají Ortiz-Hernández ${ }^{1^{*}}$ (D) Teodulfo Aquino-Bolaños ${ }^{1}$ (i) \\ Serafín Cruz-Izquierdo ${ }^{2}$ (])
}

${ }^{1}$ Instituto Politécnico Nacional, Centro Interdisciplinario de Investigación para el Desarrollo Integral Regional Unidad Oaxaca (CIIDIROaxaca), Santa Cruz Xoxocotlán, 71230, Oaxaca, México. E-mail: yortiz@ipn.mx. "Corresponding author.

${ }^{2}$ Colegio de Postgraduados, Campus Montecillo, Recursos Genéticos y Productividad, Fisiología Vegetal, Montecillo, Estado de México, México.

ABSTRACT: The diversity of chilis in Oaxaca is one of the most extensive in Mexico. Growers select seeds in the traditional manner; information on its quality is unknown. The aim of this research was to compare the physical and physiological quality of seeds and seedlings of three native types to chili (Huacle, De agua and Pasilla) and of the commercial Green pepper as control. Fifteen variables were evaluated in seed and twelve in seedlings. The laboratory experiments were established under a completely randomized design. Means of the variables were compared using the Tukey test $(\alpha=0.05)$. Results showed that Pasilla chili had the highest values in seed size and weight, which was 1.44 $g$ heavier than the control and 2.09 to $3.73 \mathrm{~g}$ higher than native types. Haucle chili and green pepper had a $90 \%$ germination rate, while chili De agua and Pasilla chili had germination rates of 51 and 38\%, respectively. Huacle chili had the highest germination rate index (29.89) and seedling vigor index (992.25). The top highest values of number of normal seedlings were obtained in the control and Huacle chili seedlings (72 and 88\%); also, the latter had the longest plumule $(3.36 \mathrm{~cm})$ and radicle $(7.67 \mathrm{~cm})$ values. Both Huacle and Pasilla chili seedlings had larger values in height, stem thickness, number of leaves, leaf area and slenderness index than De agua and Green pepper. Huacle chili had good physical and physiological quality similar to the seeds of the commercial Green pepper.

Key words: germination, morphometry seed, vigor, genotype.

\author{
Qualidade de sementes e plântulas de três pimentas (Capsicum annuum L.) \\ endêmicas de Oaxaca, México
}

\begin{abstract}
RESUMO: Oaxaca é umas das regiões de maior diversidade de espécies de pimentas do México. Os agricultores selecionam sementes da maneira tradicional; informações sobre sua qualidade são desconhecidas. O objetivo desta pesquisa foi comparar a qualidade fisica e fisiológica de sementes e mudas de três tipos nativos de pimenta (Huacle, De Agua e Pasilla) e pimenta verde comercial como controle. Quinze variáveis foram avaliadas em sementes e doze em mudas. As experiências de laboratório foram estabelecidas sob um delineamento inteiramente casualizado. As médias das variáveis foram comparadas pelo teste de Tukey ( $\alpha=0.05)$. Os resultados mostraram que o Pasilla apresentou os maiores valores em tamanho e peso de sementes, 1,44 g mais pesado que o controle e 2,09 a 3,73 g maior que os demais tipos de pimenta nativa. A pimenta Huacle e a pimenta verde tiveram $90 \%$ de germinação de $90 \%$, enquanto que De Agua e Pasilla foi de 51 e $38 \%$, respectivamente. A pimienta Huacle apresentou os maiores índices de taxa de germinação (29,89) e de vigor de plântulas (992,25). Os maiores valores máximos no número de mudas normais foram obtidos no controle e na pimenta Huacle (72 e 88\%). Além disso, este último apresentou os maiores valores de plúmula $(3,36 \mathrm{~cm})$ e radicula $(7,67 \mathrm{~cm})$. As mudas do Huacle e Pasilla apresentaram maiores valores em altura, espessura do caule, número de folhas, área foliar e índice de esbelto em relação à pimenta, De agua e ao controle. O Huacle apresentou boa qualidade física e fisiológica, semelhante às sementes da pimentão comercial.

Palavras-chave: germinação, morfometria de sementes, vigor, genótipo.
\end{abstract}

\section{INTRODUCTION}

The genus Capsicum spp. includes around 30 species, of which $C$. annuum, $C$. chinense and $C$. frutescens are the most widely cultivated (MOQUAMMEL et al., 2016). The species C. annuum L. is the most widely distributed and important in the world due to its different uses and its excellent adaptation (TOLEDO-AGUILAR et al., 2016).

In Mexico there is a great diversity of chilis with different physical, chemical and organoleptic characteristics (GONZÁLEZ-CORTÉS et al., 2015). In 2018 production of green fresh chilies in Mexico was 3.1 million $t$, a third of which was exported 
to the United States and Europe (SIAP, 2018). In Oaxaca, 2519.6 ha were cultivated with chili in 2017, outstanding of which were Jalapeño, Serrano and Green pepper (SIAP, 2017), as well as native chilis: De agua, Pasilla and Huacle, among others.

Mexican chili growers use seed size as the selection criterion. In this respect, AYALAVILLEGAS et al. (2014) stated that the profitability of a crop is related to seed quality, which involves genetic, phytosanitary, physical and physiological characteristics (BARCHENGER \& BOSLAND, 2016).

Germination is the most critical phase of the plant life cycle (BARCHENGER \& BOSLAND, 2016). In cultivated species there is a direct positive correlation between seed weight and seedling growth from emergence and lengthening of the hypocotyl up to detachment of the cotyledons (MORENO-PÉREZ et al., 2011).

Moreover, seedling quality can be evaluated by means of physical (height, stem diameter and weight), physiological (net assimilation rate, absolute growth rate and relative growth rate) and morphological (slenderness index) parameters (GARCÍA-MORALES et al., 2011; GUZMÁNANTONIO et al., 2012; CORTÉS-FLORES et al., 2016).

Due to the above and the scarce or nonexistent information on seed quality and seedling growth of native chilis to Oaxaca, the objective of this study was to compare physical and physiological quality of the seeds and seedlings of Huacle, Pasilla and De agua chilis.

\section{MATERIALS AND METHODS}

\section{Source and distinctive characteristics of plant material}

Seed of the native chilis was provided by growers of the region of Oaxaca where each chili originated. Chilis differed in color, odor, flavor and stage of maturity for consumption (Figure 1). Huacle chili, from San Juan Bautista, Cuicatlán, located at $17^{\circ} 48^{\prime} \mathrm{N}$ and $96^{\circ} 57^{\prime} \mathrm{W}, 620 \mathrm{~m}$ above sea level, is consumed dry. Its pericarp is smooth, shiny, dark brown in color and aromatic. De agua chili from Ocotlán de Morelos, Central Valleys of Oaxaca, located at $16^{\circ} 48^{\prime} \mathrm{N}$ and $96^{\circ} 40^{\prime} \mathrm{W}, 1500 \mathrm{~m}$ altitude, with average annual temperature of $26.9{ }^{\circ} \mathrm{C}$, is consumed fresh. It has bright green pericarp. Pasilla chili, from Santa María Alotepec, Sierra Norte (Mixe) located at $17^{\circ} 05^{\prime} \mathrm{N}$ and $95^{\circ} 51^{\prime} \mathrm{W}$, at an altitude of $1460 \mathrm{~m}$ with an average annual temperature of $20^{\circ} \mathrm{C}$, is consumed smoke-dried. It is highly aromatic and has a wrinkled shiny dark red pericarp (Figures 1 and 2).

The capsaicin and dihydrocapsaicin contents $\left(\mathrm{mg} \mathrm{kg}^{-1}\right)$ and pungence in Scoville units

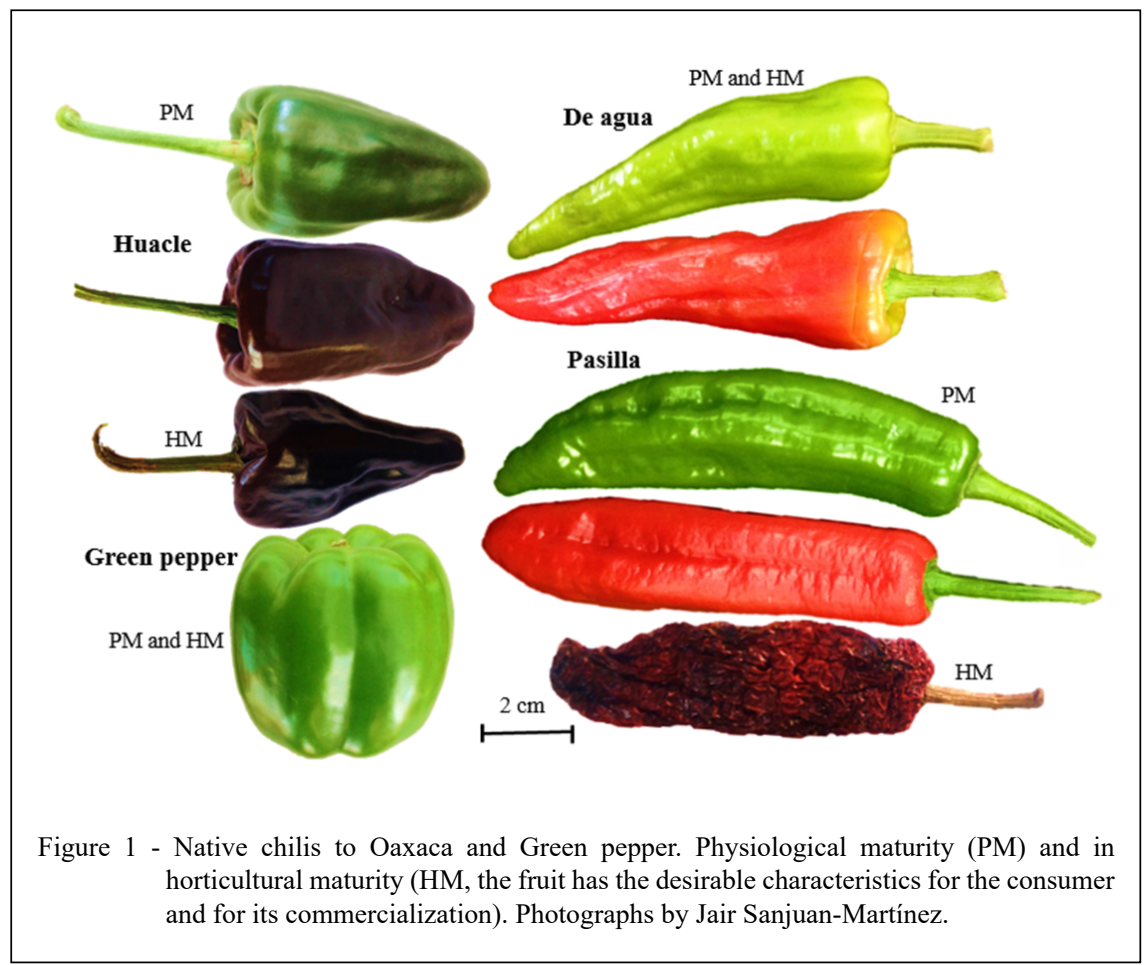

Ciência Rural, v.50, n.9, 2020. 


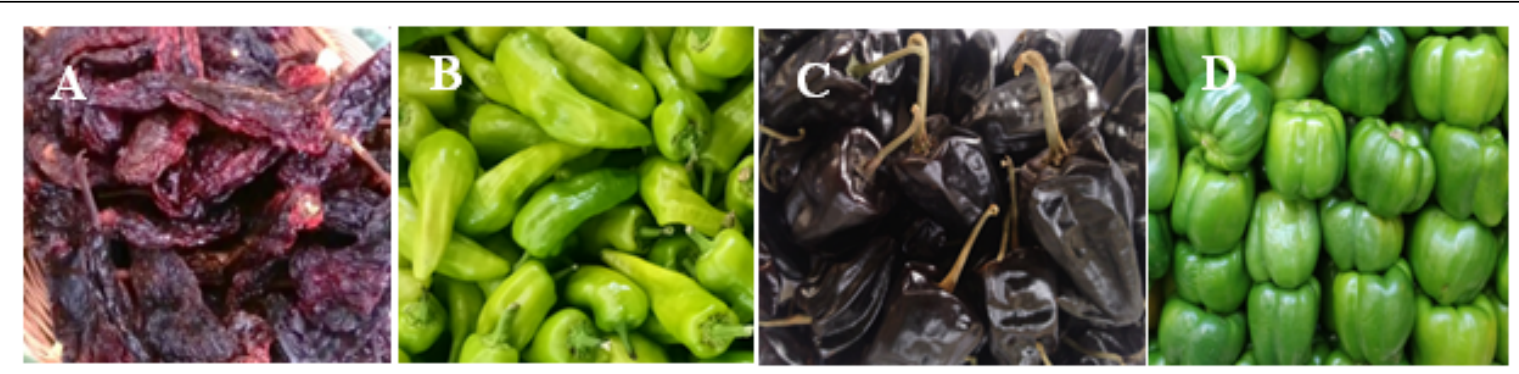

Figure 2 - Native chilis of Oaxaca in markets for commercialization. A) Pasilla, B) De agua, C) Huacle and D) Green pepper (control). Photographs by Jair Sanjuan-Martínez.

(SHU) for dry Huacle chili were 161, 47 and 6420 (GARCÍA-GAYTÁN et al., 2017). For fresh chile De agua, the values were 44, 42 and no SHU data (MARTÍNEZ-MARTÍNEZ, et al., 2014). Fresh Pasilla chili had values of 49, 69 and 1899 (ORELLANA-ESCOBEDO et al., 2013) and in dry Pasilla (1000 to $4000 \mathrm{SHU}$ ). In Green pepper the values reported are 1.0, not detected and 15.83 (AL OTHMAN, et al., 2011).

\section{Seed bed}

The seedbed was established in a growth chamber Biotronette Mark III Lab-Line ${ }^{\circledR}$ (Melrose Park, IL USA), which provided fluorescent light for $14 \mathrm{~h}$ with four Philips lamps (TL40W/54RS) and a temperature of $25{ }^{\circ} \mathrm{C} \pm 2{ }^{\circ} \mathrm{C}, 85-90 \% \mathrm{RH}$. The seedbed consisted of polystyrene trays with 200 cavities with Sphagnum peat and agrolite (2:1) substrate. One previously disinfected seed was placed in each cavity and covered with a layer of vermiculite and watered every $24 \mathrm{~h}$ with a $25 \%$ Steiner solution using a manual sprinkler can.

Seeds

Seed size (SS). Four replications of 100 seeds (ISTA, 2012) of each chili genotype (Figure 3) were digitalized, and the resulting images were processed with the software Image J 1.5 (National Intitutes of Health, USA). The obtained parameters were area, perimeter, length and width.

Weight of 1000 seeds (WTS). Each of eight 100-seed replications of each genotype was weighed on an analytical balance with $0.0001 \mathrm{~g}$ precision. With the values of each genotype, we calculated the mean, variance, standard deviation, and coefficient of variation, which had a value of less than 4.0. Finally, the mean was multiplied by 10 to obtain the equivalent weight of 1000 seeds (ISTA, 2012). For physiological determination of the seeds, four 25-seed replications were used as indicated by ISTA (2012).

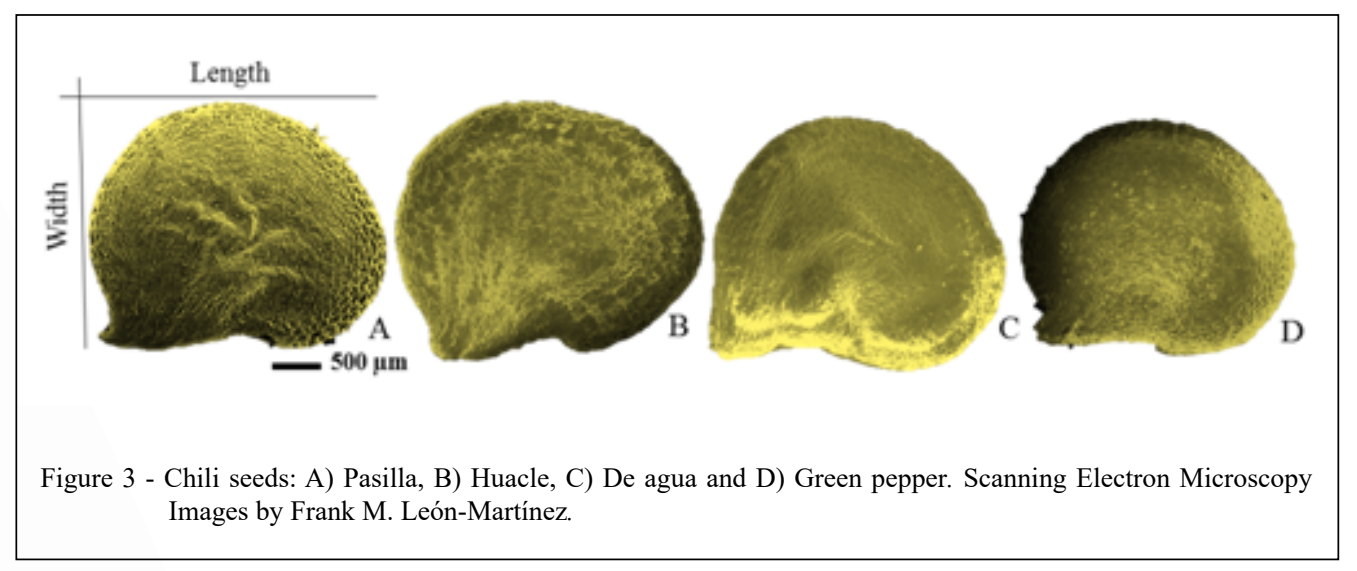

Ciência Rural, v.50, n.9, 2020. 


\section{Germination}

Seeds were disinfected by immersion for 2 min with $1 \%$ sodium hypochlorite $(\mathrm{NaClO})$, washed with distilled water for $5 \mathrm{~min}$ and placed on filter paper (Whatman ${ }^{\circledR}$ No. 44) moistened with $10 \mathrm{~mL}$ water in Petri dishes (four replications, 25 seeds per replication), which were deposited in a germination chamber at $25 \pm 1{ }^{\circ} \mathrm{C}$ and constant light (ISTA, 2012). The number of germinated seeds were counted daily for 14 days after sowing (das).

A seed was considered germinated when the radicle was at least $2 \mathrm{~mm}$ long. At the end of the test, 16 seedlings were taken at random and measured for plumule length (PL) and radicle length (RL).

With the values obtained, the following indexes were calculated:

1) Germination percentage (GP):

$\mathrm{GP}=\frac{\text { Number of seeds that have germinated }}{\text { Total number of seeds }} * 100$

2) Germination speed index (GSI), which consists of daily count of seedlings at the same time from the day normal seedlings emerged until the day of the last count, according to MAGUIRE (1962).

$\mathrm{GSI}=\frac{\mathrm{S} 1}{\mathrm{~T} 1}+\frac{\mathrm{S} 2}{\mathrm{~T} 2}+\frac{\mathrm{S} 3}{\mathrm{~T} 3}+\cdots \frac{\mathrm{Sn}}{\mathrm{Tn}}$

Where: S1, S2, S3..., Sn = Number of seedlings in the first, second, third and last counts; and, T1, T2, $\mathrm{T} 3 \ldots, \mathrm{Tn}=$ Time in days for each germination.

3) Mean daily germination (MDG), calculated as the ratio between the accumulated percentage of germinated seeds at the end of the assay and the number of days from sowing until the end of the trial. 4) Germination value (GV), considered as germination quality, according to DJAVANSHIR \& POURBEIK (1976).

$\mathrm{GV}=\frac{\sum \mathrm{DGS}}{\mathrm{N}} * \frac{\mathrm{GP}}{10}$

Where: DGS = Daily germination speed. $\mathrm{N}=$ Number of DGS, number of days since beginning the test. $\mathrm{GP}=$ Germination percent.

5) Seedling vigor index (SVI), according VANSTADEN et al. (2006),

where, SVI $=($ hypocotyl length + radicle length $){ }^{*}$ GP

\section{Seedlings}

At 33 das, 20 seedlings of each genotype were sampled randomly, and using the destructive method, the following parameters were obtained: plant height ( $\mathrm{PH}$, from the stem base to the apex), stem diameter ( $\mathrm{SD}$, measured $1 \mathrm{~cm}$ above the substrate), number of leaves (NL), fresh weight (FW), radicle length (RadL, from the stem base to the tip of the longest radicle), radicle volume ( $\mathrm{RV}$, by complete submersion of the root zone in water in a $10 \mathrm{~mL}$ test tube), leaf area (LA, using digitalized images of the leaves of each seedling). Leaf area was analyzed with the software Image J 1.5 (National Institutes of Health, USA). Finally, the seedlings were dried at $75^{\circ} \mathrm{C}$ for $72 \mathrm{~h}$ to obtain dry weight (DW). Also, the slenderness index (SI) was calculated with the ratio between $\mathrm{PH}(\mathrm{cm})$ and $\mathrm{SD}(\mathrm{mm})$, as indicated by GUZMÁN-ANTONIO et al. (2012).

Following the methodology of CORTÉSFLORES et al. (2016), dry matter and leaf area of 20 seedlings of each genotype were quantified on days 19, 26 and 33 after sowing to obtain the following indexes: net assimilation rate (NAR), absolute growth rate (AGR) and relative growth rate (RGR).

The experimental design was completely randomized, and all the data were subjected to analysis of variance (ANOVA). Means of the variables were compared by the Tukey test $(\alpha=0.05)$, and correlation analysis also perfomed. The software program used to anlyze the data was $\mathrm{SAS}^{\circledR} 9.1$ (SAS, 2004). Prior to the analysis germination percentages (x) were transformed using the arcsine function $\sqrt{ } \mathrm{x} / 100$. Graphs were made using Microsoft Excel ${ }^{\circledR}$.

\section{RESULTS AND DISCUSSION}

Seeds

Significant differences $(\mathrm{P} \leq 0.05)$ were reported for the variables 1000 seed size and weight. The area of Pasilla seeds was $1.56 \mathrm{~mm}$ larger than that of Huacle seeds and 3.07 to $3.16 \mathrm{~mm}$ larger than De agua chili and Green pepper seeds. Moreover, 1000 Pasilla seeds weighed $1.44 \mathrm{~g}$ more than seeds of the control and 2.09 to $3.73 \mathrm{~g}$ more than seeds of the other chilis (Table 1), and correlations between these variables were highly significant (Table 2). HERNÁNDEZ-VERDUGO et al. (2010) also reported variation in seed weight among wild chili populations and plants in the state of Sinaloa, Mexico. Despite the differences between the native chilis and the control, seed size was similar to the dimensions (5.3 $\mathrm{mm}$ long and $4.3 \mathrm{~mm}$ wide) of a typical Capsicum annuum seed (BOSLAND \& VOTAVA, 2012).

\section{Germination and seedlings}

Huacle and the control had the highest germination percentages $(90 \%)$, similar to the $95 \%$ for Habanero seeds (GARRUÑA-HERNÁNDEZ et al., 2014). For the other chilis, the lowest percentages were close to the 57, 43 and $27 \%$ reported for Capsicum annuum genotypes Habanero, Amashito 
Table 1 - Physical characteristics of chili seeds (Capsicum annuum L.). Oaxaca, México. 2018.

\begin{tabular}{lccccc}
\hline Genotype & Lenght $(\mathrm{mm})$ & Width $(\mathrm{mm})$ & Perimeter $(\mathrm{mm})$ & Area $\left(\mathrm{mm}^{2}\right)$ & Weight of $1000 \mathrm{seeds}(\mathrm{g})$ \\
\hline Huacle & $4.93 \mathrm{~b}$ & $4.10 \mathrm{~b}$ & $15.44 \mathrm{c}$ & $15.92 \mathrm{~b}$ & $6.12 \mathrm{~b}$ \\
Pasilla & $5.13 \mathrm{a}$ & $4.33 \mathrm{a}$ & $17.13 \mathrm{a}$ & $17.48 \mathrm{a}$ & $8.21 \mathrm{a}$ \\
De agua & $4.57 \mathrm{c}$ & $3.98 \mathrm{c}$ & $16.31 \mathrm{~b}$ & $14.32 \mathrm{c}$ & $4.48 \mathrm{c}$ \\
Green pepper & $4.57 \mathrm{c}$ & $4.00 \mathrm{c}$ & $14.96 \mathrm{~d}$ & $14.41 \mathrm{c}$ & $6.77 \mathrm{~b}$ \\
\hline
\end{tabular}

Averages with different letters in columns present a significant difference (Tukey, $\mathrm{P} \leq 0.05$ ).

and Chiltepín, respectively (ARAIZA-LIZARDE et al., 2011; GONZÁLEZ-CORTÉS et al., 2015; MOOMUÑOS et al., 2016). The variation in germination percentage can be attributed to factors such as genotype, stage of maturation of the fruit during seed extraction, plant physical state, and latency, among other (AYALA-VILLEGAS et al., 2014; BARCHENGER \& BOSLAND, 2016).

Seedling characteristics (Table 3) were significantly different $(\mathrm{P} \leq 0.05)$. There were $16 \%$ more normal Huacle chili seedlings than the control and $60 \%$ more than De agua chili and Green pepper. Moreover, Huacle had longer plumule and radicle than the other chilis. The optimum percentage for commercial production of seedlings should be 80 to $90 \%$ (LÓPEZBALTAZAR et al., 2013). In this respect, Huacle chili seedlings are within the optimum index because $88 \%$ of the plantlets were normal. Values for plumule and radicle in the other chili genotypes are similar to those reported in Green pepper by GUZMÁN-
MURILLO et al. (2013) in a range of 1.96 to 2.39 (plumule) and 4.72 to $9.08 \mathrm{~cm}$ (radicle). The seed weight is correlated with seedling growth, except for Pasilla chili seeds, which were heavier weight but had a lower percentage of normal seedlings.

Germination indexes were significantly different $(\mathrm{P} \leq 0.05)$ among the genotypes (Table 3). Huacle chili seeds had higher GSI (29.89) and SVI (992.25), and the ADG (6.42) and GV (2.57) were similar to those of the control. The difference between the obtained values was caused by the variation in germination rate (Figure 4). Huacle chili seeds reached their peak germination percentage at 7 das, while germination of De agua and Pasilla chilis was slower. Size of the plumule and radicle affected the germination indexes.

Seedling growth after appearance of true leaves was linear and ascendant (Figure 5). The final height of Huacle and Pasilla chilis was superior to the control and chili De agua by $41 \%$. In this respect,

Table 2 - Correlations between seed variables of chili seeds (Capsicum annuum L.). Oaxaca, México. 2018.

\begin{tabular}{|c|c|c|c|c|}
\hline \multirow[t]{2}{*}{ Variables } & \multicolumn{4}{|c|}{ 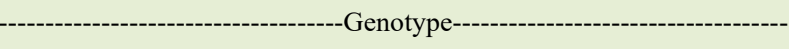 } \\
\hline & Huacle & Pasilla & De agua & Green pepper \\
\hline Area vs Perimeter & $0.981^{* *}$ & $0.106 \mathrm{~ns}$ & $0.837^{* *}$ & $0.941^{* *}$ \\
\hline Area vs Lenght & $0.908^{* *}$ & $0.890^{* *}$ & $0.867^{* *}$ & $0.959^{* *}$ \\
\hline Area vs Width & $0.925^{* *}$ & $0.860^{* *}$ & $0.909^{* *}$ & $0.928^{* *}$ \\
\hline Perimeter vs Lenght & $0.912^{* *}$ & $0.28 \mathrm{~ns}$ & $0.853^{* *}$ & $0.945^{* *}$ \\
\hline Perimeter vs Width & $0.890^{* *}$ & $-0.143 n s$ & $0.653^{* *}$ & $0.820^{* *}$ \\
\hline Lenght vs Width & $0.682^{* *}$ & $0.533^{* *}$ & $0.582^{* *}$ & $0.786^{* *}$ \\
\hline Germination vs Germination rate index & $0.774^{* *}$ & $0.905^{* *}$ & $0.944^{* *}$ & $0.774^{* *}$ \\
\hline Plumule vs Radicle & $0.676^{* *}$ & $0.794^{* *}$ & $0.241 \mathrm{~ns}$ & $0.232 \mathrm{~ns}$ \\
\hline Germination rate index vs Average daily germination & $0.774^{* *}$ & $0.905^{* *}$ & $0.944^{* *}$ & $0.774^{* *}$ \\
\hline Germination rate index vs Germination value & $0.774^{* *}$ & $0.905^{* *}$ & $0.944^{* *}$ & $0.774^{* *}$ \\
\hline Germination rate index vs Seedling vigor index & $0.774^{* *}$ & $0.905^{* *}$ & $0.944^{* *}$ & $0.774^{* *}$ \\
\hline
\end{tabular}

${ }^{* *}=$ Highly significant $(\mathrm{P} \leq 0.01), \mathrm{ns}=$ Not significant. 
Table 3 - Characteristics of germinated seeds, seedlings and germination indexes of Capsicum annuum L. Oaxaca, México. 2018.

\begin{tabular}{|c|c|c|c|c|}
\hline \multirow[t]{2}{*}{ Variables } & \multirow[b]{2}{*}{ Huacle } & \multirow[b]{2}{*}{ Pasilla } & \multirow[b]{2}{*}{ De agua } & \multirow[b]{2}{*}{ Green pepper } \\
\hline & & & & \\
\hline NS (\%) & $88 \mathrm{a}$ & $22 b$ & $16 \mathrm{~b}$ & $72 \mathrm{a}$ \\
\hline AS (\%) & $2 \mathrm{c}$ & $16 \mathrm{~b}$ & $35 \mathrm{a}$ & $19 \mathrm{ab}$ \\
\hline DS (\%) & $10 \mathrm{a}$ & $62 \mathrm{~b}$ & $49 \mathrm{~b}$ & $9 \mathrm{a}$ \\
\hline PL (cm) & $3.36 \mathrm{a}$ & $2.69 \mathrm{~b}$ & $1.94 \mathrm{c}$ & $2.54 \mathrm{~b}$ \\
\hline RadL (cm) & $7.67 \mathrm{a}$ & $4.98 \mathrm{~b}$ & $3.95 \mathrm{~b}$ & $5.28 \mathrm{~b}$ \\
\hline G (\%) & $90 \mathrm{a}$ & $38 \mathrm{~b}$ & $51 \mathrm{~b}$ & $91 \mathrm{a}$ \\
\hline GSI & 29.89 a & $3.29 \mathrm{~d}$ & $9.00 \mathrm{c}$ & $19.16 \mathrm{~b}$ \\
\hline $\mathrm{ADG}$ & $6.42 \mathrm{a}$ & $2.71 \mathrm{~b}$ & $3.64 \mathrm{~b}$ & $6.50 \mathrm{a}$ \\
\hline $\mathrm{GV}$ & $2.57 \mathrm{a}$ & $1.08 \mathrm{~b}$ & $1.45 \mathrm{~b}$ & $2.60 \mathrm{a}$ \\
\hline SVI & $992.25 \mathrm{a}$ & $291.17 \mathrm{c}$ & $300.26 \mathrm{c}$ & $711.50 \mathrm{~b}$ \\
\hline
\end{tabular}

Averages with different letters in horizontal lines present a significant difference (Tukey, $P \leq 0.05$ ). NS $=$ Normal seedlings, AS $=$ Abnormal seedlings, DS = Dead seeds, PL = Plum length, RadL = Radicle length, G = Germination, GSI = Germination Speed Index; $\mathrm{ADG}=$ Average Daily Germination; $\mathrm{GV}=$ Germination Value; SVI = Seedling Vigor Index

it has been reported that plants need to be 10 to 15 cm for transplanting (RAMALHO DO RÊGO et al., 2016; MORENO-PÉREZ et al., 2011). In a similar experiment, TOLEDO-AGUILAR et al. (2016) reported that Poblano chili reaches this height 68 to 77 das, while diverse studies of Green pepper report a wider range (18 to 60 das) to reach the same height (RAMALHO DO RÊGO et al., 2016; MORENOPÉREZ et al., 2011). Likewise, average heights of 6.5 $\mathrm{cm}$ for Chiltepín seedlings treated with gibberellic acid (ARAIZA-LIZARDE et al., 2011), $12 \mathrm{~cm}$ for Onza chili (LÓPEZ-BALTAZAR et al., 2013) and

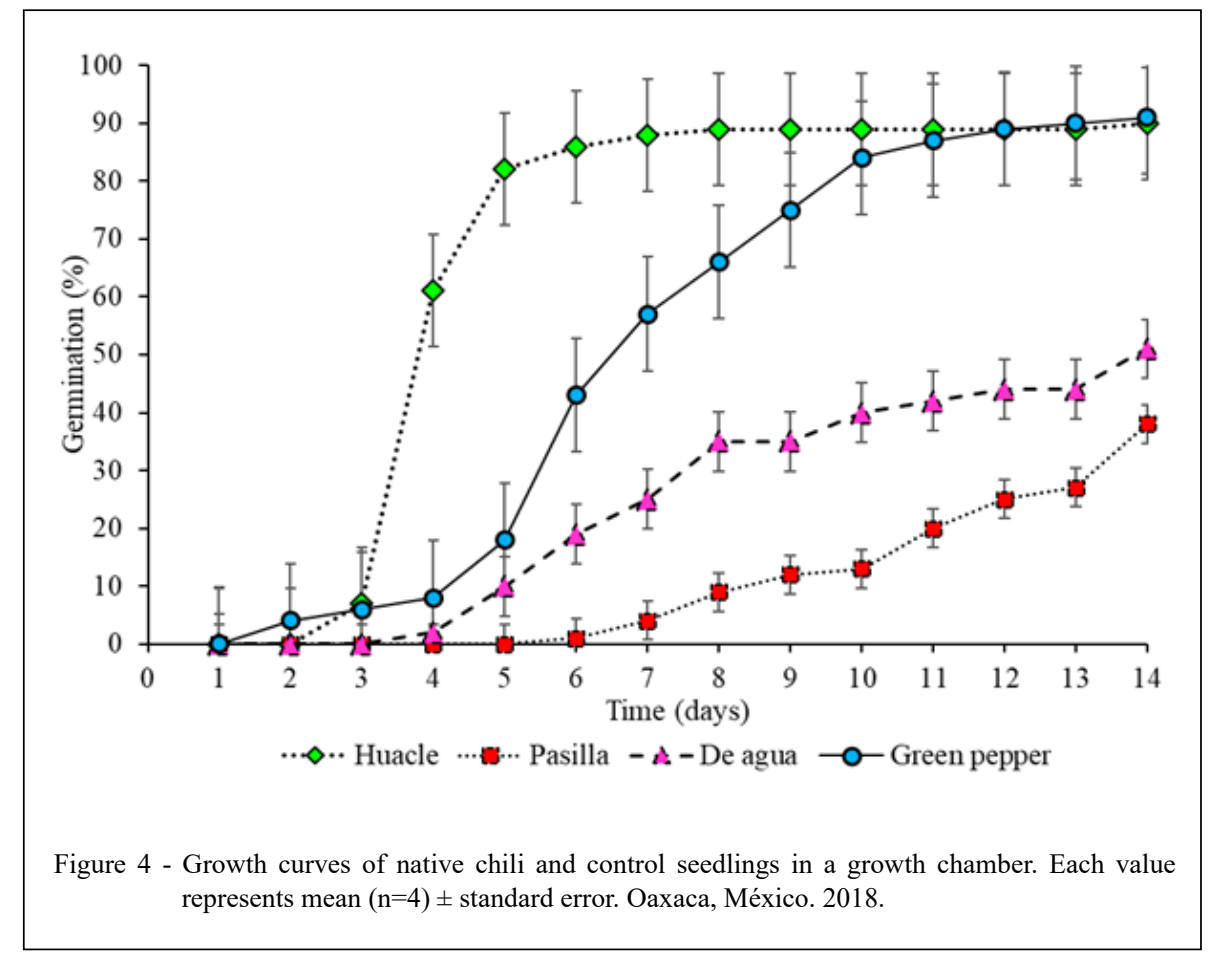

Ciência Rural, v.50, n.9, 2020. 


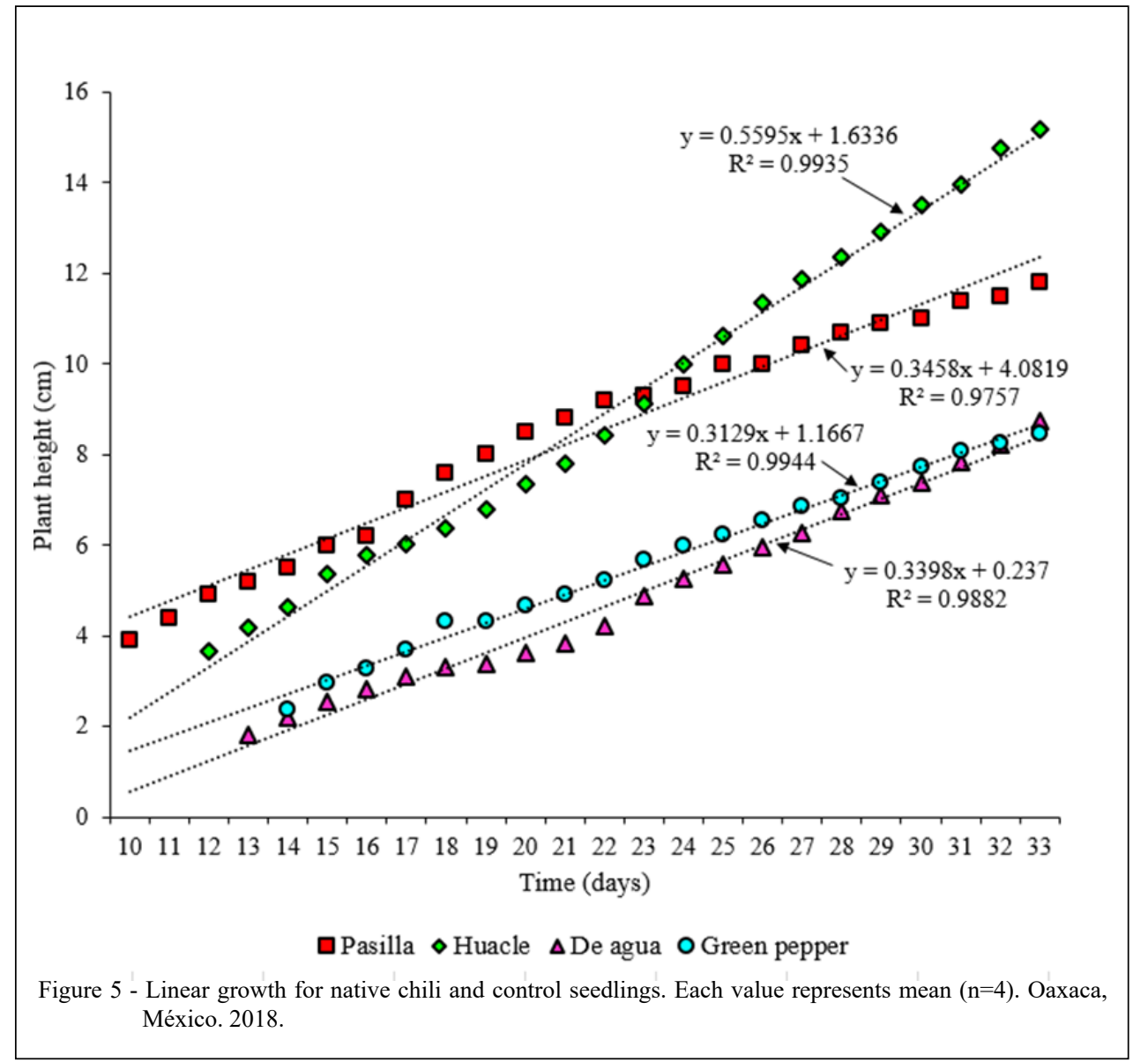

a maximum height of $29.8 \mathrm{~cm}$ for Habanero chili treated with rhizobacteria (CASTILLO-AGUILAR et al., 2017). Besides height, several authors point out that a seedling should have four to eight true leaves before transplanting (RAMALHO DO RÊGO et al., 2016; MORENO-PÉREZ et al., 2011). Seedlings of our study were all within that range (Table 4). However, MOO-MUÑOS et al. (2016) stated that the seed drying method is a factor that affects seedling characteristics and growth.

Cultivars were significantly different $(\mathrm{P} \leq 0.05)$ in seedling morphological parameters (Table 4). Except for root length and volume, Huacle and Pasilla chilis had higher parameter values. Although, the control was shorter and had fewer leaves, accumulation of dry matter and leaf area were similar to those of Huacle and Pasilla chilis. Stem diameter of the genotypes was similar to the $2.0 \mathrm{~mm}$ reported by LÓPEZ-BALTAZAR et al. (2013) in Onza chili seedlings and within the range of 1.37 to $2.55 \mathrm{~mm}$ reported by CASTILLO-AGUILAR et al. (2017) in Habanero chili seedlings 40 das. In terms of root length, all the values were above the range of 2.89 to $4.43 \mathrm{~cm}$ reported for Green pepper seedlings (PUERTA et al., 2012). The same authors indicated the presence of four to eight leaves on seedlings and 0.20 to $1.02 \mathrm{~g}$ fresh matter. Table 4 shows that the seedlings of native chilis, including the control, had higher fresh weight and number of leaves than that reported by PUERTA et al. (2012).

In table 4 it can be observed that the values of dry matter were higher than the $0.12 \mathrm{~g}$ found in Poblano chili (GARCÍA-MORALES et al., 2011) and the $0.14 \mathrm{~g}$ in Onza chili (LÓPEZ-BALTAZAR et al., 2013). Also, leaf area values were higher than the $13 \mathrm{~cm}^{2}$ reported by GONZÁLEZ-MANCILLA et al. (2017) in Poblano chili seedlings and less than the 90.12 $\mathrm{cm}^{2}$ reported for Habanero chili seedlings (CASTILLOAGUILAR et al., 2017). In terms of growth indexes, the seedlings had significant differences $(\mathrm{P} \leq 0.05)$ due to the differences in height and stem diameter. Relative growth rate was higher in the control, indicating greater accumulation of biomass. 
Table 4 - Morphological characteristics and growth index of Capsicum annuum L. Oaxaca, México. 2018.

\begin{tabular}{|c|c|c|c|c|}
\hline \multirow[t]{2}{*}{ Variables } & \multirow[b]{2}{*}{ Huacle } & \multirow[b]{2}{*}{ Pasilla } & \multirow[b]{2}{*}{ De agua } & \multirow[b]{2}{*}{ Green pepper } \\
\hline & & & & \\
\hline $\mathrm{PH}(\mathrm{cm})$ & $14.98 \mathrm{a}$ & $14.22 \mathrm{a}$ & $8.61 \mathrm{~b}$ & $8.53 \mathrm{~b}$ \\
\hline $\mathrm{SD}(\mathrm{mm})$ & $2.30 \mathrm{a}$ & $2.26 \mathrm{a}$ & $1.76 \mathrm{~b}$ & $1.87 \mathrm{~b}$ \\
\hline $\mathrm{RL}(\mathrm{cm})$ & $4.55 \mathrm{a}$ & $5.07 \mathrm{a}$ & $4.03 \mathrm{a}$ & $5.65 \mathrm{a}$ \\
\hline $\mathrm{RV}\left(\mathrm{cm}^{3}\right)$ & $2.4 \mathrm{a}$ & $2.1 \mathrm{a}$ & $1.6 \mathrm{a}$ & $2.5 \mathrm{a}$ \\
\hline $\mathrm{FW}(\mathrm{g})$ & $1.83 \mathrm{a}$ & $1.90 \mathrm{a}$ & $1.21 \mathrm{~b}$ & $1.54 \mathrm{ab}$ \\
\hline DW (g) & $0.18 \mathrm{ab}$ & $0.20 \mathrm{a}$ & $0.13 \mathrm{c}$ & $0.15 \mathrm{ab}$ \\
\hline NL & $7 \mathrm{a}$ & $8 \mathrm{a}$ & $5 \mathrm{~b}$ & $4 \mathrm{~b}$ \\
\hline $\mathrm{LA}\left(\mathrm{cm}^{2}\right)$ & $60.25 \mathrm{a}$ & $62.03 \mathrm{a}$ & $43.61 \mathrm{~b}$ & $48.48 \mathrm{~b}$ \\
\hline SI & $6.55 \mathrm{a}$ & $6.31 \mathrm{a}$ & $5.01 \mathrm{~b}$ & $4.60 \mathrm{~b}$ \\
\hline $\operatorname{NAR}\left(\mathrm{g} \mathrm{cm}^{2} \mathrm{~d}^{-1}\right)$ & $0.08 \mathrm{a}$ & $0.05 \mathrm{a}$ & $0.08 \mathrm{a}$ & $0.11 \mathrm{a}$ \\
\hline $\operatorname{AGR}\left(\mathrm{g} \mathrm{d}^{-1}\right)$ & $0.01 \mathrm{a}$ & $0.01 \mathrm{a}$ & $0.01 \mathrm{a}$ & 0.01 a \\
\hline $\operatorname{RGR}\left(\mathrm{g}^{-1} \mathrm{~d}^{-1}\right)$ & $0.09 \mathrm{a}$ & $0.07 \mathrm{~b}$ & $0.06 \mathrm{~b}$ & $0.15 \mathrm{a}$ \\
\hline
\end{tabular}

Averages with different letters in horizontal lines present a significant difference (Tukey, $P \leq 0.05$ ); PH $=\mathrm{Plant}$ Height; SD $=\mathrm{Stem}$ Diameter; RL = Root Length; RV = Root Volume; FW = Fresh Weight; DW = Dry Weight; NL = Number of Leaves; LA = Leaf area, $\mathrm{SI}=$ Slenderness Index; NAR $=$ Net Assimilation Rate; AGR $=$ Absolute Growth Rate; RGR $=$ Relative Growth Rate

\section{CONCLUSION}

There were differences in the physical and physiological quality of seed and seedlings among native chilis and also when they were compared to the commercial Green pepper. Huacle chili had as good physical-physiological quality of seeds and seedlings as the commercial Green pepper chili.

\section{ACKNOWLEDGEMENTS}

The authors gratefully acknowledge to Instituto Politécnico Nacional (IPN) for the financial support (Project code: SIP20180619 and SIP20200340) and the facilities to carry out this research, and COFAA-IPN for financial support to this publication. To the growers of Oaxaca for supporting us with the material of native chilis (Capsicum annuun). MSc Frank León Martínez by Scanning Electron Microscopy Images. As well as the Consejo Nacional de Ciencia y Tecnología (CONACyT) for the scholarship of the first author.

\section{DECLARATION OF CONFLICT OF INTERESTS}

The authors declare no conflict of interest. The founding sponsors had no role in the design of the study; in the collection, analyses, or interpretation of data; in the writing of the manuscript, and in the decision to publish the results.

\section{AUTHORS' CONTRIBUTIONS}

All authors contributed equally for the conception and writing of the manuscript. All authors critically revised the manuscript and approved of the final version.

\section{REFERENCES}

AL OTHMAN, Z. A. et al. Determination of capsaicin and dihydrocapsaicin in Capsicum fruit samples using high performance liquid chromatography. Molecules, v.16, p.8919-8929, 2011. Available from: <https://doi.org/10.3390/molecules16108919>. Accessed: Aug. 13, 2018. doi: 10.3390 /molecules16108919.

ARAIZA LIZARDE, N. et al. Evaluation of germination and seedling growth of chiltepín (Capsicum annuum L variedad glabriusculum) greenhouse. Revista Colombiana de Biotecnología, v.13, p.170-175, 2011. Available from: <http:// www.scielo.org.co/pdf/biote/v13n2/v13n2a16.pdf >. Accessed: Jun. 07, 2018.

AYALA VILLEGAS, M. J. et al. Seed quality evolution of Capsicum annuum L. through different fruit development stages. Revista Fitotecnia Mexicana, v.37, p.79-87, 2014. Available from: $<$ https://www.revistafitotecniamexicana.org/documentos/37-1/8a. pdf>. Accessed: Sep. 23, 2018.

BARCHENGER, W. D. BOSLAND, P. W. Exogenous applications of capsaicin inhibits seed germination of Capsicum annuum. Scientia Horticulturae, v.203, p.29-31, 2016. Available from: $<$ https://doi.org/10.1016/j.scienta.2016.03.009>. Accessed: Aug. 12, 2018. doi: 10.1016/j.scienta.2016.03.009.

BOSLAND, P. W.; VOTAVA, E. J. Peppers: Vegetable and Spice Capsicums. (2nd ed., p.230) CABI, USA. 2012.

CASTILLO AGUILAR, C. C. et al. Evaluation of rhizobacteria strains in the production of habanero chili (Capsicum chinense Jacq.) seedlings. Agroproductividad, v.10, p.128-133, 2017. Available from: <http:// www.revista-agroproductividad.org/index.php/agroproductividad/article/ view/49/45>. Accessed: Jul. 20, 2018.

CORTÉS FLORES, C. et al. Iodine increases the growth and mineral concentration in sweet pepper seedlings. Agrociencia,

Ciência Rural, v.50, n.9, 2020. 
v.50, p.747-758, 2016. Available from: <https://www.colpos. $\mathrm{mx} /$ agrocien/Bimestral/2016/ago-sep/art-7.pdf $>$. Accessed: May, 15, 2019.

DJAVANSHIR, K.; POURBEIK, H. Germination value-A new formula. Silvae Genetica, v.25, p. 79-83, 1976. Available from: $<$ https:// www.thuenen.de/media/institute/fg/PDF/Silvae Genetica/1976/ Vol._25_Heft_2/25_2_79.pdf $>$. Accessed: Jun. 05, 2018.

GARCÍA MORALES, C. et al. Seedling quality of "Poblano" pepper in the Sierra Nevada of Puebla, México. Revista Fitotecnia Mexicana, v.34, p.115-121, 2011. Available from: <https:// www.revistafitotecniamexicana.org/documentos/34-2/6a.pdf>. Accessed: Sep. 16, 2018.

GARCÍA GAYTÁN, V. et al. The chilhuacle chili (Capsicum annuum L.) in Mexico: Description of the variety, its cultivation, and uses. International Journal of agronomy, v.5, p.1-13, 2017. Available from: <https://doi.org/10.1155/2017/5641680>. Accessed: Aug. 18, 2018. doi: 10.1155/2017/5641680.

GARRUÑA HERNÁNDEZ, R. et al. Pre-sowing treatments: an option to increase germination of habanero pepper seeds (Capsicum chinense Jacq.). Agrociencia, v.48, p.413-423, 2014. Available from: <https://www.colpos.mx/agrocien/ Bimestral/2014/may-jun/art-6.pdf>. Accessed: Jul. 22, 2018.

GONZÁLEZ CORTÉS, N. et al. Germination of amashito chili (Capsicum annuиm L. Var. Glabriusculum) in southeastern México. Revista Mexicana de Ciencias Agrícolas, v.11, p.2211-2218, 2015. Available from: <https://doi.org/10.29312/remexca.v0i11.800>. Accessed: Jun. 26, 2018. doi: 10.29312/remexca.v0i11.800.

GONZÁLEZ MANCILLA, A. et al. Caracterización y selección de rizobacterias promotoras de crecimiento en plántulas de chile poblano (Capsicum аппиит L.). Revista Internacional de Contaminación Ambiental, v.33, p.463- 474, 2017. Available from: $<$ http://dx.doi. org/10.20937/RICA.2017.33.03.09>. Accessed: Sep. 18, 2018. doi: 10.20937/RICA.2017.33.03.09.

GUZMÁN ANTONIO, A. et al. Effect of the salicylic acid and nutrition on quality of habanero pepper seedlings. Agronomía Mesoamericana, v.23, p.247-257, 2012. Available from: $<$ https://revistas.ucr.ac.cr/index.php/agromeso/ article/view/6485>. Accessed: Sep. 10, 2018. doi: 10.15517/ AM.V23I2.6485.

GUZMÁN MURILLO, M. A. et al. Germination and ROS detoxification in bell pepper (Capsicum annuиm L.) under $\mathrm{NaCl}$ stress and treatment with microalgae extracts. Protoplasma, v.250, p.33-42, 2013. Available from: <https://doi.org/10.1007/ s00709-011-0369-Z>. Accessed: Aug. 12, 2018. doi: 10.1007/ s00709-011-0369-z.

HERNÁNDEZ VERDUGO, S. et al. Variation in germination among populations and plants of wild chili pepper. Agrociencia, v.44, p.667-677, 2010. Available from: <https://www.colpos. $\mathrm{mx} /$ agrocien/Bimestral/2010/ago-sep/art-6.pdf $>$. Accessed: Jul. 10, 2018.

ISTA. International Rules for Seed Testing. Zurich, Switzerland International Seed Testing Association, 2012. p.243.

LÓPEZ BALTAZAR, J. et al. Agronomic evaluation of substrates in pepper seedlings "onza" (Capsicum annuum) in greenhouse.
Revista Mexicana de Ciencias Agrícolas, v.6, p.1139-1150, 2013. Available from: <https://doi.org/10.29312/remexca. v0i6.1278>. Accessed: Sep. 04, 2018. doi: 10.29312/ remexca. v0i6.1278.

MARTÍNEZ MARTÍNEZ, R. et al. Interpopulation heterosis for agromorphology and capsaicinoids in native peppers from Oaxaca. Revista Fitotecnia Mexicana, v.37, p.199-207, 2014. Available from: <https://www.revistafitotecniamexicana.org/ documentos/37-3/2a.pdf $>$. Accessed: Jun. 09, 2018.

MAGUIRE, J. D. Speed of germination-aid in selection and evaluation for seedling emergences and vigor. Crop Science, v.2, p.176-177, 1962. Available from: <https:// dl.sciencesocieties.org/publications/cs/abstracts/2/2/ CS0020020176>. Accessed: Aug. 30, 2018. doi: 10.2135/crop sci1962.0011183X000200020033x.

MOO MUÑOS, A. J. et al. Effect of maturity and drying of Capsicum chinense Jacq. seeds on the germination and physiological quality of the seedling. Agroproductividad, v.9, p.63-67, 2016. Available from: <http://www.revistaagroproductividad.org/index.php/agroproductividad/article/ view/709/578>. Accessed: Sep. 28, 2018.

MORENO PÉREZ, E. del C. et al. Phenology and yield of bell pepper (Capsicum annuum L.) hybrids grown hydroponically. Revista Chapingo Serie Horticultura, v.17, p.5-18, 2011. Available from: <https://chapingo.mx/revistas/horticultura/ contenido.php?id articulo $=1229 \&$ id revistas $=1 \&$ id revista numero $=114>$. Accessed: Jul. 20, 2018.

MOQUAMMEL, S. K. H. et al. Karyological studies of two hot chilli pepper cultivars from two different geographical regions of India: Bhut jolokia, Capsicum chinense Jacq. and Bullet Lanka, Capsicum annuum L. The Nucleus, v.59, p.227-233, 2016. Available from: <https://link.springer.com/article/10.1007\%2 Fs13237-016-0180-5>. Accessed: Sep. 25, 2018. doi: 10.1007/ s13237-016-0180-5.

ORELLANA ESCOBEDO, L. et al. Capsaicinoids content and proximate composition of Mexican Chili peppers (Capsicum spp.) cultivated in the State of Chihuahua. CyTA Journal of Food, v.11, p.1-6, 2013. Available from: <https://doi.org/10.1 080/19476337.2012.716082>. Accessed: Aug. 15, 2018. doi: 10.1080/19476337.2012.716082.

PUERTA, A. C. E. et al. Seedling production of bell pepper (Capsicum annuum L.) in organic substrates based in coconut fiber mixtures. Revista Científica UDO Agrícola, v.12, p.298-306, 2012. Available from: <http://udoagricola. orgfree.com/V12N2UDOAg/V12N2Russian298.pdf >. Accessed: Jul. 04, 2018

RAMALHO DO RÊGO, E. et al. Production and breeding of chilli peppers (Capsicum spp.). Springer, New York, 2016. p.134. ISBN 978-3-319-06531-1, ISBN 978-3-319-06532-8 (eBook). Available from: <https://link.springer.com/content/ pdf/10.1007\%2F978-3-319-06532-8.pdf $>$. Accessed: Aug. 15, 2018. doi: 10.1007/978-3-319-06532-8.

SAS. User's guide, SAS/ETS 9.1. SAS Institute Inc. Cary, NC, USA. 2004. 2426p. Available from: <https://support.sas.com/ documentation/onlinedoc/91pdf/sasdoc_91/ets_ug_7314.pdf > Accessed: Jan. 27, 2019. 
SIAP. Servicio de Información Agroalimentaria y Pesquera. Anuario estadístico de la producción agrícola de Chile en Oaxaca. 2017. Available from: <https://nube.siap.gob.mx/cierreagricola/>. Accessed: Apr. 06, 2019.

SIAP. Servicio de Información Agroalimentaria y Pesquera. Planeación agrícola Nacional 2017-2030. 2018. Chiles y Pimientos. Available from: $<$ https://www.gob.mx/cms/uploads/... file/.../Potencial-Chiles_y_Pimientos-parte_uno.pdf $>$. Accessed: Apr. 07, 2019.
TOLEDO AGUILAR, R. et al. Morphological diversity of native population's poblano pepper. Revista Mexicana de Ciencias Agrícolas, v.7, p.1005-1015, 2016. Available from: <https://doi.org/10.29312/remexca. v7i5.227>. Accessed: Jun. 23, 2018. doi: 10.29312/remexca.v7i5.227.

VAN-STADEN, J. et al. Post- germination effects of the smoke-derived compound 3-methyl-2H-furo[2,3-c]pyran-2-one, and its potential as a preconditioning agent. Field Crops Research, v.98, p.98-105, 2006. Available from: <https://doi.org/10.1016/j.fcr.2005.12.007>. Accessed: Sep. 05, 2018. doi: 10.1016/j.fcr.2005.12.007. 